\title{
Şişli Hamidiye Etfal Eğitim ve Araştırma Hastanesi'nde Çalışan Veri Hazırlama ve Kontrol İşletmenlerinin İş Memnuniyet ve Kuruma Bağlılık Düzeyleri Üzerine Bir Araştırma
}

\section{Yıldız Köse' ${ }^{1}$ Yeliz Leblebici ${ }^{1}$, Hatice Çakmakcı ${ }^{1}$, Güven Bektemür²}

\begin{abstract}
ÖZET:
Şişli Hamidiye Etfal Eğitim ve Araştırma Hastanesi'nde çalışan veri hazırlama ve kontrol işletmenlerinin iş memnuniyet ve kuruma bağlılık düzeyleri üzerine bir araştırma

Amaç: Her sağılık çalışanı, sağlık hizmetleri sektörünün önemli bir parçasıdır. Herhangi bir alandaki olumsuzluk sağlık çalışanlarını etkilediği gibi, sektörün diğer çalışanlarını da etkilemektedir. Teknolojinin gelişmesi, sağlık sektöründe daha ileri ve üst düzey hizmet intiyacı yaratmış ve çalışan gücünün vasıfıı olmasını zorunlu hale getirmiştir. Bu vasıfı insan gücünün de verimli olması için kurumdan memnun olması ve kurumsal bağlılık düzeyinin de yüksek olması gerekmektedir. Çünkü memnun olan personel daha üretken ve mesleğine daha bağlı olmaktadır. Bu çalışmanın amacı, i̇stanbul Şişli Hamidiye Etfal Eğitim ve Araştırma Hastanesi'nin çeşitli birimlerde görev yapan Veri Hazırlama ve Kontrol İşletmenlerinin mesleğinden, çalışma koşullarından ve kurumdan memnun olma durumlarını belirlemek ve kurumdan ayrılıp ayrılmama yönündeki düşüncelerini saptayıp iyileştirme faaliyetlerinde kuruma rehberlik etmektir.

Gereç ve Yöntem: Bu çalışma kapsamında, istanbul Şişli Hamidiye Etfal Eğitim ve Araştırma Hastanesi'nde çeşitli birimlerde görev yapan Veri Hazırlama ve Kontrol İşletmenlerinin işinden, çalışma koşullarından ve çalıştığı kurumdan memnun olma durumlarını belirlemek ve kurumdan ayrılıp ayrılmama düsünncelerini sorgulamak amaçlı anket soruları hazırlanmış ve kurum Etik Kurul onayı alındıktan sonra 201 çalışana uygulanmıştır. Uygulanan anket verileri bilgisayara ortamına aktarıldıktan sonra tanımlayıcı analizler ve hipotezlere yönelik istatistiksel analiz için SPSS 15.0 for Windows programı kullanıımışıtır. Tanımlayıcı istatistikler; kategorik değişkenler için sayı ve yüzde, sayısal değişkenler için ortalama, standart sapma olarak verilmiştir. Kategorik değişkenlerin gruplar arasındaki oranları Ki Kare Analizi ile test edilmiştir. Koşulların sağlanamadığı durumda Monte Carlo simülasyonu uygulanmış̧ır. İstatistiksel alfa anlamlılık seviyesi p<0.05 olarak kabul edilmiştir. Bulgular: Çalışanlar \%41.8'i Şişli Hamidiye Etfal'de çalış̧maktan memnun olduğunu belirtmiştir. \%44.8 kısmen memnun olduğunu, \%13.4'ü memnun olmadığını belirtmiştir. Kısmen memnun olan ve memnun olmayanların en büyük gerekçesi \% 59.5 oranla aldığı maaşın yetersiz olmasını gerekçe göstermiştir. Çalışanların \%42.3'ü, kurumdan ayrılmayı düşünüyor musunuz? sorusuna hayır cevabı vermiştir. \%21.4'ü evet, \%36.3'ü kısmen cevabı vermiştir. Ayrılmayı düşünen grubun \%62.1 oranla gerekçesini aldığı maaşın düşük olması olarak belirtilmiştir. Çalışanların yaş grupları ile kurumdan ayrılmayı düşünmme durumları arasında $p=0.015<0.05$ oranında anlamlı ilişki bulunmuştur. Kurumdan ayrılmayı düşünmmeyenlerde \%22.4 oranla Şişli Etfal'li olmayı sevdiklerini belirtmişlerdir.

Sonuç: Çalış̧ma sonunda;

- Çalışanların kurumun fiziki koşullarından çok memnun olmadığı,

- Çalışma arkadaşları ile iletişimlerinin iyi olduğu

- Görev dağııımda adil olunduğunu dair inancın düsük olduğu,

- Kurum içi iletișimin düșük olduğu ve kuruma bağlılık düzeyinin düșük olduğu

• Kurumda performans değerlendirme ölçütlerinin uygulandığına dair inancın düşük olduğu, Yöneticilerle ilişkilerinin düşük düzeyde olduğu - Kurumda algıladıkları sosyal olanakların düşük olduğu,

- Eğitim faaliyetleri ve Kalite çalışmaları konusunda yeterince aktif ve katıımcı olmadıkları sonucuna ulaşılmıştır.

Veri Hazırlama ve Kontrol İșletmenlerinin, kurumdan ayrılmayı düșünmelerinin en büyük nedeni ise aldıkların ücretin yetersiz olduğunu düşünmeleridir. Veri Hazırlama ve Kontrol İşletmenlerinin memnuniyet artıırıp kuruma bağlamak amaçlı çözümler geliștirilmelidir. Bunun için mesleki memnuniyet düzeylerini olumsuz etkileyen faktörlere karşı önlem alınmalı, sosyal imkânları arttırılmalı, beklentilerine yönelik yönetim stratejileri geliştirilmelidir.

Anahtar kelimeler: Veri kontrol ve hazırlama işletmeni, memnuniyet, hastane
\end{abstract}

ABSTRACT:

A survey about job satisfaction and loyalty of data processing and control operators in Şişli Hamidiye Etfal Education and Research Hospital

Objective: All health care workers, are important parts of the health care sector.As negative effects in any other field affect health professionals, also affects other employees in the sector. The development of technology in the health sector has created the recuirements for more advanced and high level of service and has made employee strength, mandatory to be qualified. These skilled people has to be satisfied with the institutions to be efficient in power and the institutional commitment levels should be high. Because more pleased staffs satisfied with the institutions to be efficient in power and the institutional commitment levels should be high. Because more pleased staffs
are more productive and professional. The purpose of this study is to check satisfaction and working conditions of various units serving in are more productive and professional. The purpose of this study is to check satisfaction and working conditions of various units serving in
Data Processing and Control Operators in Istanbul Sisli Hamidiye Etfal Education and Research Hospital, and detect their thoughts about Data Processing and Control Operators in Istanbul Sisli Hamidiye Etfal Education and Research Hosp
to leave their procession in organization and guide to the instution about redevelopment acitivities.

to leave their procession in organization and guide to the instution about redevelopment acitivities.
Material and Method: In this study we purpose to survey about satisfaction and working conditions of various units serving in Data Material and Method: In this study we purpose to survey about satisfaction and working conditions of various units serving in Data
Processing and Control Operators in Istanbul Sisli Hamidiye Etfal Education and Research Hospital, and detect their thoughts about to Processing and Control Operators in Istanbul Sisli Hamidiye Etfal Education and Research Hospital, and detect their thoughts about to
leave their procession and the questions were prepared and receive approval from Ethics Committee has been applied to 201 employees. leave their procession and the questions were prepared and receive approval from Ethics Committee has been applied to 201 employees. After applied survey data being transferred to the computer, for statistical analysis about descriptive analysis and hypothesis, SPSS 15.0 ables are given as the standard deviation. Percentages of categorical variables among groups was tested by chi square analysis. In cases where requirements are not met Monte Carlo simulation is applied. Statistical significance level of alpha has been accepted as p<0.05 Results: The employees stated that of their $41.8 \%$ enjoyed working in the Sisli Hamidiye Etfal. $44.8 \%$ were partially satisfied, $13.4 \%$ Results: The employees stated that of their $41.8 \%$ enjoyed working in the Sisli Hamidiye Etfal. $44.8 \%$ were partially satisfied, $13.4 \%$
were not satisfied. The common argument of the partially satisfied and dissatisfied was unsatisfactory money for life. (59.5\%) $42.3 \%$ of employees about leaving the organization has 'no ' answer to the question. $21.4 \%$ yes, $36.3 \%$. maybe. The group who were thinking about employees about leaving the organization has "no "answer to the question. $21.4 \%$ yes, $36.3 \%$. maybe. The group who were thinking about the organization, there was percent significant relationship ( $p=0.015<0.05$ percent). The thinking about to stay in the instution, $22.4 \%$ of the organization, there was percent significant relationship
the employee stated that they liked to be from Sissli Etfal.

the employee stated that they liked

Conclusion: At the end of the study;
- The employees of institutions were not satisfied with the physical conditions,

- Have good communication with work colleagues,

- The belief about justice in the task distribution was low.

- The communication in the instution was poor and the loyalty to the instution was not enough.

- The belief that the implementation of the performance evaluation criteria in the institution is low, it was the low level of relations with the Director,

- Social opportunities, of the instution were not enough.

- They were not sufficiently active in training activities and quality studies and concluded they were not participants.

Data Processing and Control operators' the biggest reason for thinking of leaving the organization was that the salary rates insufficient for life. Because of it, the satisfaction of this employee must be higher. The measures to be taken against factors that negatively affect their professional satisfaction, social services should be increased, management strategies should be developed to expectations.

Key words: operator control and data preparation, satisfaction, hospital

Ş.E.E.A.H. Tıp Bülteni 2015;49(3):207-13
'Şişli Hamidiye Etfal Eğitim ve Araştırma Hastanesi, Sağlık Bakım Hizmetleri Müdürlüğü, İstanbul - Türkiye

2istanbul Beyoğlu Kamu Hastaneleri Birliği Genel Sekreterliği, İstanbul - Türkiye

Yazışma Adresi / Address reprint requests to: Yıldız Köse,

Şişli Hamidiye Etfal Eğitim ve Araştırma Hastanesi, Sağlık Bakım Hizmetleri Müdürlüğü, İstanbul - Türkiye

Telefon / Phone: +90-212-373-5346

E-posta / E-mail:

yzkose@gmail.com

Geliş tarihi / Date of receipt:

16 Haziran 2015 / Jule 16, 2015

Kabul tarihi / Date of acceptance:

10 Ağustos 2015 / August 10, 2015 


\section{GíRiş}

İş, yaşamın vazgeçilmez bir parçasıdır. Çalışanlar yaklaşık 25-30 yıllık bir süre boyunca, gününün önemli bir kısmını iş yerinde geçirmektedir. Bu nedenle çalışanın işinden doyum sağlaması psikolojik ve fiziksel sağlığı açısından son derece önemlidir. Başka bir deyişle kişinin mutlu olması ve yaşamından haz alması için iş doyumu gereklidir. Zira belli bir örgütte çalışan birey, zamanının büyük bir bölümünü iş ortamında geçirmekte; burada gerçekleştirmesi gereken ve kendisinden beklenen görevler sonucunda da "örgütsel stres" kavramı ortaya çıkmaktadır (1). Bu nedenle çalışanı geliştirmek ve zenginleştirmek suretiyle doyumunu arttırma çabası, tarih boyunca öncelikli olarak dikkate alınan konu olmuştur.

Çağdaş yöneticilerden, çalışanların iş doyumlarının sağlanması ve artırılması için gereken önlemleri almaları beklenmektedir. Her şeyden önce, iş doyumunu sağlamak için yöneticilerin mevcut önyargılarından kurtulmaları gerekmektedir. Yöneticiler, çalışanların sadece ekonomik bir varlık olmadığını, aynı zamanda sosyal yönlerinin de bulunduğunu, ekonomik beklentilerinin yanında farklı sosyo-psikolojik beklentilerini ve gereksinimlerini karşılamak için bir örgütte çalıştıklarını göz önünde bulundurmalıdırlar. Bu çerçevede, çalışanların iş doyumlarının sağlanması aynı zamanda örgütlerin sosyal görevidir (2). Her sağlık çalışanı, sağlık hizmetleri sektörünün önemli bir parçasıdır. Medikal sistemlerinin ve bilgisayar teknolojinin gelişmesi, hasta bakımında, hasta memnuniyetinde daha ileri-üst düzey hizmet ihtiya$\mathrm{Cl}$, sağlık endüstrisinde çalışan gücünün sayısını arttırmış ve vasıflı insan gücünü gerekli hale getirmiştir.

Bu çalışmada sağlık çalışanlarının bir parçası olan Veri Hazırlama ve Kontrol İşletmenlerinin memnuniyetinin ve kuruma bağlılık düzeylerinin araştırılması planlanmıştır. Çıkan sonuç üzerinden iyileştirme, memnuniyeti arttırma ve kurumsal bağlılığı artırma faaliyetlerinde hastane yönetimine rehberlik etmek amaçlanmıştır.

\section{GEREÇ VE YÖNTEM}

Araştırmada kullanılan anket beş bölümden oluşmaktadır. Birinci bölümde demografik faktörler, ikin- ci bölümde veri giriş elemanlarının iş yerindeki çalışma koşulları ve uygulamalar hakkındaki görüşleri, üçüncü bölümde, veri giriş elemanlarının Şişli Hamidiye Etfal EAH 'de çalışmaktan memnun olma durumları, dördüncü bölümde, veri giriş elemanlarının kurumdan ayrılma ve ayrılmama hakkındaki görüşleri, beşinci bölümde, veri giriş elemanlarının en önemli gördükleri sorunlarını saptamaya yönelik sorular sorulmuştur. Değişkenleri ölçülebilir duruma getirmek ve cevaplayıcılara yeterli alternatif sunarak yanıtlama zamanını ve çabasını en aza indirmek için 2. bölümde tüm maddeler beşli Likert tipi ölçek formatında hazırlanmıştır. Diğer bölümlerde de üçlü Likert tipi ve çoklu cevaplı sorular hazırlanmıştır. Şişli Hamidiye Etfal EAH Etik Kurul'undan uygulanılabilir onayı alındıktan sonra kurumda çeşitli birilerde çalışan Veri Hazırlama ve Kontrol İşletmenlerinin 201 tanesine anket uygulanmıştır. Araştırmanın amacına uygun olarak hazırlanan anket verilerinin yapılması sağlanıp, bilgisayar ortamına aktarıldıktan sonra tanımlayıcı analizler ve hipotezlere yönelik istatistiksel analiz için SPSS 15.0 for Windows programı kullanılmıştır. Tanımlayıcı istatistikler; kategorik değişkenler için sayı ve yüzde, sayısal değişkenler için ortalama, standart sapma olarak verilmiştir. Kategorik değişkenlerin gruplar arasındaki oranları Ki Kare Analizi ile test edilmiştir. Koşulların sağlanamadığı durumda Monte Carlo simülasyonu uygulanmıştır. İstatistiksel alfa anlamlılık seviyesi $\mathrm{p}<0.05$ olarak kabul edilmiştir.

\section{BULGULAR}

Çalışmaya dahil edilen Veri Hazırlama ve Kontrol İşletmenlerinin çeşitli özelliklerine göre dağılımı Tablo 1'de gösterilmiştir.

\section{Araştırma Grubunun İşyerindeki Çalışma Koşulları ve Uygulamalar Hakkındaki Görüşleri}

Fiziki Koşullar: Çalışanların \%35'i hastanede klimatizasyon sistemini yetersiz olduğu, \%30,8'i de iş yeri güvenlik önlemlerinin yeterli olmadığı yönünde olumsuz görüş bildirirken, \%27,9'u çalışma ortamında çalıştığım işe uygun yerleşim düzeni var olarak olumlu görüş bildirmiştir. 
Tablo 1: Veri Hazırlama ve Kontrol işletmenlerinin çeşitli özelliklerine göre dağılımı

\begin{tabular}{|c|c|c|c|}
\hline & & Sayı & $\%$ \\
\hline \multirow[t]{5}{*}{ Yaş } & $18-25$ yaş & 33 & 16.4 \\
\hline & $26-30$ yaş & 48 & 23.9 \\
\hline & $31-35$ yaş & 67 & 33.3 \\
\hline & $36-40$ yaş & 29 & 14.4 \\
\hline & 41 yaş üstü & 24 & 11.9 \\
\hline \multirow[t]{2}{*}{ Cinsiyet } & Erkek & 58 & 28.8 \\
\hline & Kadın & 143 & 71.1 \\
\hline \multirow[t]{2}{*}{ Medeni } & Evli & 106 & 53.8 \\
\hline & Bekar & 95 & 47.2 \\
\hline \multirow[t]{4}{*}{ Eğitim } & Lise & 115 & 57.5 \\
\hline & Ön lisans & 37 & 18.4 \\
\hline & Lisans & 42 & 21.0 \\
\hline & Yüksek lisans & 7 & 3.1 \\
\hline \multirow[t]{3}{*}{ Birim } & Poliklinik sekreterliği & 61 & 30.8 \\
\hline & Klinik sekreterliği & 56 & 27.8 \\
\hline & Diğer & 84 & 41.4 \\
\hline \multirow[t]{3}{*}{ Statü } & Kadrolu & 19 & 8.5 \\
\hline & Sözleşmeli & 63 & 31.3 \\
\hline & Hizmet alım & 119 & 59.2 \\
\hline
\end{tabular}

Çalışma Arkadaşları ile iletişim: Çalışanların, \%44.8'i "çok iyi", \%25.4 "iyi" olarak olumlu görüş bildirmişlerdir.

Görev Dağılımı: Çalışanların, \%28.9'u iş yükü dağılımının adil yapılmadığını düşünmekte, \%24.9'u da Kurumda görev, yetki ve sorumluluklar açıkça tanımlanmadığını söylemektedir.

Kurumsal Bağlılık: Çalışanların \%30’u çalışma arkadaşları ile arasında ortak kurumsal değer ve inanç paylaşımı olduğunu düşünmekte, \%31.8'i çalışma arkadaşları ile ilişkileri karşılıklı güvene dayalı olduğunu düşünmekte, \%30.3'ü Şişli Hamidiye Etfal EAH'nde çalışmaktan gurur duymaktadır.

Kurum İçi İletişim: Çalışanların \%25.6'sı hastane işleyişine ilişkin bilgilerin zamanında iletildiğini, \%29.4 hastanede elektronik iletişim teknolojisinden yeterince yararlanıldığını düşünmektedir. \%34.2'si hastane işleyişi ile ilgili gereksiz formalitelerin olduğunu, \%34.3'ü iletişim kanallarının etkili bir şekilde kullanıldığını düşünmektedir.

Performans Değerlendirme: Çalışanların \%32.8'i çalışma performansım değerlendirildiğine ve sonuçları tarafına bildirildiğine kesinlikle katılmamakta, \%31.3'ü de ücret politikasının performansımı olumsuz yönde etkilediğine kesinlikle katılmaktadır. \%38.3'ü Kurum içi terfilerde adalet ve eşitlik ilkesine uyulduğu görüşüne kesinlikle katılmamaktadır. \%49.8'i kurumda yapılan işe uygun ücretin ödendiğini düşünüyorum sorusuna kesinlikle katılmamaktadır. \%37'si kurumda başarıların takdir edildiğini kesinlikle düşünmemektedir.

Yönetici ile illişkiler: Çalışanların \%32.3'ü yönetici ile ilişkilerin karşılıklı güven esasına dayandı̆̆ını düşünmekte, \%33'ü iş yerinde yapılan hataların yönetici tarafından toleransla karşılandığı konusunda kararsız olduğunu belirtmektedir. \%31.3'ü ise "yöneticim işim konusunda rehberlik etmektedir" düşüncesine katılmaktadır.

Sosyal Olanaklar: Çalışanların büyük bir kısmı "kurumumuzda sosyal aktivitelere (kutlamalar, konserler. vb.) önem verilmektedir" düşüncesine katılmamaktadır (\%25.9 katılmıyor, \%31.3 kesinlikle katılmıyor). \%23.9'luk bir kısım da "düzenlenen sosyal aktiviteler iş verimini arttırdığını düşünüyorum" görüşüne katılmaktadır.

Hizmet İçi Eğitim: Çalışanların \%34.3'ü "düzenlenen hizmet içi eğitimler ihtiyaca yöneliktir" görüşüne katılmakta; \%36.8'i "kurumumda eğitim olanakları yeterlidir" sorusunda kararsız kalmaktadır. \%27.4'ü "düzenlenen eğitimler mesleki bilgi düzeyime fayda sağlamaktadır" düşüncesine katılmaktadır.

Kalite Yönetim Sistemi: Çalışanların \%29.9'u "Kalite Yönetim Sistemi" çalışmaları hakkında yeterli bilgiye sahip olduğuna ve katıldığını ifade etmekte, kalite yönetim sistemi çalışmalarının iş süreçlerini olumlu etkilediğini düşünmektedir.

\section{Veri Giriş Elemanlarının Şişli Hamidiye Etfal EAH'de Çalışmaktan Memnuniyet Durumu}

Çalışanların \%41.8'i hastanede çalışmaktan memnunken, \%13.4'ü memnuniyetsiz olup, \%44.8'i kısmen memnun olduğunu ifade etmiştir. Hayır ve kısmen cevabı verenlerin \%59.5'i memnuniyetsizliğinin nedenini aldığı maaşın yetersiz olduğundan kaynaklandı̆̆ını belirtmiştir.

\section{Veri Giriş Elemanlarının Kurumdan Ayrılma Ve Ayrılmama Hakkındaki Görüşleri}

Çalışanların \%21.4'ü kurumdan ayrılmayı düşündüğünü, \%42.3'ü ayrılmayı düşünmediğini, \%36.3'ü 
de kısmen cevabı ile kararsızlığını belirtmiştir. Evetkısmen cevabı verenlerin en büyük nedeni \%62.1 ile aldığı maaşın yetersiz olması iken, Hayır-kısmen cevabı verenlerin \%22.4'i Şişli Etfal'li olmayı sevdiğini, \%20.4'ü de ulaşımın kolay olduğu için kurumdan ayrılmayı düşünmediğini ifade etmiştir.

\section{Veri Giriş Elemanlarının En Önemli Gördükleri Sorunları}

"Veri Giriş Elemanlarının en önemli sorunları nedir?" sorusuna \%82.6 oranla "aldıkları ücretin yetersizliği" cevabı verilmiştir. Çalışanların duygu ve düşüncelerini anlatabileceği bu tarz anketlerin yapılmasını desteklemeye ise \%42.3 oranla hayır cevabı verilmiştir. Çalışanların verdiği cevaplara ilişkin ayrıntılar Tablo 2'de verilmiştir.

Tablo 2: Veri giriş elemanlarının en önemli gördükleri sorunlar

\begin{tabular}{lcc}
\hline $\begin{array}{l}\text { Veri Giriş elemanlarının şu anki en } \\
\text { temel sorunu sizce nelerdir? }\end{array}$ & $\mathbf{n}$ & \% \\
\hline Ücret yetersizliği & 166 & 82.6 \\
Risk fazlalığı & 1 & 0.5 \\
İstenilen branşta çalışamama & 4 & 2.0 \\
Görev yetki sorumluluklarının belli olmaması & 7 & 3.5 \\
Yoğun çalışma temposu & 7 & 3.5 \\
Görev dışı işlerde çalıştırılma & 1 & 0.5 \\
Meslekte ilerleyememe & 12 & 6.0 \\
Fazla çalışma & 3 & 1.5
\end{tabular}

Veri Giriş Elemanlarının Yaş Gruplarına Göre Kurumdan Memnuniyet Durumu ve Kurumdan Ayrılıp-Ayrılmama Hakkındaki Görüşleri

Araştırma kapsamında "Veri Giriş Elemanlarının Yaş Gruplarına Göre Kurumdan Memnuniyet Durumu ve Kurumdan Ayrılıp-Ayrılmama Hakkındaki Görüşleri" incelenmiştir. 45 yaş üstünde olan grup kurumdan memnun olma durumu ile ilgili \%58.3 ile kısmen cevabı vermiştir. 26-30 yaş grubu çalışanlar \%50 oranında kısmen memnun olduğunu belirtmiştir. Yaş grupları ile veri giriş elemanlarının memnuniyetleri arasında anlamlı düzeyde bir ilişki bulanamamıştır ( $p>0.05$ ). "Veri giriş elemanlarına kurumdan ayrılmayı düşünüyor musunuz?" sorusu sorulmuş ve 45 yaş üstü grup \%54.2 oranı ile "hayır" cevabı ver- miştir. "Kurumdan ayrılmayı düşünüyor musunuz?" sorusuna evet-kısmen cevabı veren 36-45 yaş grubu bunun en büyük nedenini \%77.4 oranla aldığı ücretin yetersiz olmasına bağlamıştır. Evet ve kısmen cevabı veren 45 yaşüstü grup ise neden olarak \%54.5 oranla iş yükünü fazla olduğunu söylemiştir. Çalışanların yaş grupları ile kurumdan ayrılmayı evet-kısmen isteme durumları arasında $p=0.015<0.05$ oranında anlamlı ilişki bulunmuştur. "Kurumdan ayrılmayı istiyor musunuz?" sorusuna hayır-kısmen cevabı veren 45 yaş üstü grup, neden ayrılmak istemediğini \%36.8 oranla Şişli Etfal'li olmayı sevdiğine bağlamıştır.

\section{Veri Giriş Elemanlarının Cinsiyetlerine Göre Kurumdan Memnuniyet Durumu ve Kurumdan Ayrılıp-Ayrılmama Hakkındaki Görüşleri}

Araştırma kapsamında "Veri Giriş Elemanlarının Cinsiyet Gruplarına Göre Kurumdan Memnuniyet Durumu ve Kurumdan Ayrılıp-Ayrılmama Hakkındaki Görüşleri" incelenmiştir. Kadın çalışanların kurumdan memnun olma durumu ile ilgili \%44.8 ile evet cevabı vermiştir. Memnun olmayan kadınların (hayırkısmen cevabı veren) \%63'ü aldığı maaşı yetersiz bulurken, erkeklerde bu oran \%52.6 çıkmıştır. Çalışanların cinsiyetleri ile kurumdan memnuniyet durumları arasında $\mathrm{p}=0.001<0.05$ oranında anlamlı ilişki bulunmuştur. Kadın çalışanların \%45.5 ile erkek çalışanların \%35.7'si kurumdan ayrılmayı düşünüyor musunuz sorusuna hayır cevabı vermiştir. Cinsiyetleri ile kurumdan ayrılmayı isteyip istememe durumları arasında anlamlı ilişki bulunamamıştır.

\section{Veri Giriş Elemanlarının Medeni Durumlarına Göre Kurumdan Memnuniyet Durumu ve Kurumdan Ayrılıp-Ayrılmama Hakkındaki Görüşleri}

Araştırma kapsamında Veri Giriş Elemanlarının Medeni Durumlarına Göre Kurumdan Memnuniyet Durumu ve Kurumdan Ayrılıp-Ayrılmama Hakkındaki Görüşleri incelenmiştir. Evlilerin memnun olma durumu \%45.3, bekarların memnun olma durumu \%37.1 bulunmuştur. Evlilerde, bekarlarda yakın oranlarda aldığı maaşı yetersiz bulmaktadır. Medeni durumları ile kurumdan memnuniyet durumları ara- 
sında anlamlı ilişki bulunamamıştır ( $p>0.05)$. Kurumdan ayrılmayı düşünme durumlarına evlilerde \%45.3 bekarlarda \%40.4 oranında hayır cevabı verilmiştir. Kurumdan ayrılmayı düşünen (evet-kısmen cevabı veren) evliler \%67.8 oranında aldığı ücreti yetersiz bulmakta, bekarlar \%53.8 oranında aldığı maaşı yersiz bulmaktadır. Çalışanların medeni durumları ile kurumdan ayrılmayı düşünme durumları arasında anlamlı ilişki bulunamamıştır ( $p>0.05$ ).

\section{Veri Giriş Elemanlarının Çalıştıkları Birimlere Göre Kurumdan Memnuniyet Durumu ve Kurumdan Ayrılıp-Ayrılmama Hakkındaki Görüşleri}

Araştırma kapsamında "Veri Giriş Elemanlarının Çalıştıkları Birimlere göre Kurumdan Memnuniyet Durumu ve Kurumdan Ayrılıp-Ayrılmama Hakkındaki Görüşleri" incelenmiştir. Klinikte çalışan veri giriş elemanları \%45.3 oranla diğer birimlerde çalışanlardan daha memnun bulunmuştur. \%42.6'sı memnun olan poliklinik çalışanları, memnuniyetsizliklerini \%66.7 oranla aldığı maaşların yetersizliğinden kaynaklandığını belirtmişlerdir. Çalışanların çalıştıkları birimler ile memnuniyet durumları arasında anlamlı ilişki bulunamamıştır ( $p>0.05)$. "Kurumdan ayrılmayı düşünüyor musunuz?" sorusuna klinik ve poliklinik alanları dışında diğer alanlarda çalışan veri giriş elemanları \%45.2 oranında evet cevabı vermiştir. Evet ve kısmen cevabı veren tüm gruplar aldığı maaşın yetersiz olduğunu belirtmiştir. Hayır ve kısmen diyenler ulaşımın kolay olduğunu ve Şişli Etfal'li olmayı sevdiklerini belirtmişlerdir (\%25). Çalışanların çalıştıkları birimler ile kurumdan ayrılmayı isteme durumları arasında durumları arasında anlamlı ilişki bulunamamıştır ( $p>0.05)$.

\section{Veri Giriş Elemanlarının Statülerine Göre Kurumdan Memnuniyet Durumu ve Kurumdan Ayrılıp-Ayrılmama Hakkındaki Görüşleri}

Araştırma kapsamında "Veri Giriş Elemanlarının statülerine göre Kurumdan Memnuniyet Durumu ve Kurumdan Ayrılıp-Ayrılmama Hakkındaki Görüşleri" incelenmiştir. Hizmet alım kapsamında çalışan veri giriş elemanları \%43.7 oranla diğer kapsamlarda çalışanlardan daha memnun bulunmuştur. Kadrolu çalışanlar \%68.4 oranında kısmen memnun olduğunu belirtmişlerdir. Sözleşmeli olarak çalışan Veri Giriş Elemanlarının \%65.7'si aldığı maaşı yetersiz bulmaktadır. Çalışanların kurumdaki çalışma statüleri ile memnuniyet durumları arasında anlamlı ilişki bulunamamıştır $(p>0.05)$. Kadrolu çalışanların \%42.1'i kurumdan ayrılmayı düşünürken, hizmet alım personelinin $\% 46.1^{\prime} i$ ayrılmayı düşünmediğini belirtmiştir. Ayrılmayı düşünen hizmet alım personeli de \%69.8 oranında aldığı maaşın düşük olmasından dolayı ayrılmayı düşündüğünü belirtmiştir. "Ayrılmayı düşünüyor musunuz?" sorusuna hayır ve kısmen diyenler de hastanenin ulaşımının kolay olduğunu ve Şişli Etfal'li olmayı sevdiklerini belirtmişlerdir (\%25). Çalışanların kurumdaki çalışma statüleri ile kurumdan ayrılmayı isteme durumları arasında durumları arasında anlamlı ilişki bulunamamıştır ( $p>0.05)$.

\section{TARTIŞMA}

Sağlık hizmetlerini sunuş biçimleri ülkelerin sosyo-ekonomik kalkınmışlık düzeyini belirleyen önemli göstergelerdendir. Sağlık kuruluşlarında hizmet sunulan toplumun sağlık ihtiyaçlarının karşılanması ve hizmet kullanıcılarının memnun edilmesi kurumsal başarı ve rekabet gücü açısından kaçınılmazdır (3). Sağlık hizmeti sunan kurumlar, yapısal ve işlevsel olarak en karmaşık örgütler arasında yer almaktadır. Yardımcı personelden, yüksek eğitimliye kadar çeşitlilik gösteren her düzeydeki personel, karmaşık ve çok pahalı teçhizat, yaşam ve ölümle ilgili faaliyetler ve ortaya çıkan stres gibi özellikleriyle sağlık işletmeleri, yapısında pek çok ekibi barındıran organizasyonlardır (4).

Hasta ile sağlık personeli etkileşimi, hasta tatmini ve hizmet kalitesini etkileyen en önemli faktörlerden biridir. Hastaların tekrar aynı kurumu tercih etmelerindeki en önemli faktör teknik ve klinik donanım değil, bireyler arası iletişim olmuştur. Yani hastaların tutum ve davranışlarını etkileyen en önemli faktör çalışanlardır. Bu sebeple kalite yönetiminde kurumlar çalışan memnuniyetine önem vermek zorundadırlar (5).

Hastanelerde çalışan sağlık personeli iş ve rol 
paylaşımında heterojen bir yapıya sahiptir. Heterojenliğin bu kadar fazla olduğu bir örgütte motivasyon ve kurumsal bağıılığın değerlendirilmesi açısından önemli sorunlar bulunmaktadır. Çünkü bu gruplar farklı ihtiyaçlara ve beklentilere sahip olacaklardır (6). Çalışan memnuniyeti anketlerinin birim bazında ve meslek grupları bazında ayrı ayrı yapılıp değerlendirilmesinin hastane çalışanlarının beklenti ve sorunlarını algılamak adına daha önemli olduğunu düşündüğümüz için bu anketi sadece Veri Hazırlama ve Kontrol İşletmenleri'ne yönelik uyguladık.

İş yaşamında çalışanlar ile çalışma koşulları arasında sürekli bir etkileşim bulunmaktadır. Yönetimin ele alması gereken önemli ve öncelikli sorunu, çalışanların mal ve hizmet üretimine üst düzeyde katılmalarını sağlayacak ve bu arada çalışanların sağlıklarının fiziksel ve ruhsal açıdan korunmasına olanak sağlayacak şekilde üretimi gerçekleştirebilmektir. Bu nedenle yönetim, çalışanlarının örgüte, örgütün kurallarına ve kendilerine karşı olan tutumlarını bilmek durumundadır. Bu çalışmada da sağlık çalışanlarının kuruma karşı tutumlarını değerlendirmek üzere çalışma işleyişi, çalışma ortamı ergonomisi, güvenlik, iş güvenliği ve yönetim ile ilgili sorular yöneltilmiş̧ir. Çalışma sonucunda; çalışma ortamı (ergonomisi, işleyiş ve işyeri-çalışan güvenliği), yönetimin tutumu (motive edici faktörler, işleyişe katılmak, ödüllendirme, sorunları iletme) ile kurumdan ayrılmayı düşünmeme arasında istatistiksel olarak anlamlı ve pozitif bir ilişki saptanmıştır. Kurumdan ayrılmama düşüncesini etkileyen temel faktörler; ücret yetersizliği, iş tanımının olmaması ve çalışılan bölümün işleyişinde önerilerin dikkate alınması olarak bulunmuştur.

İş tatmini bakımından moral kavramına da değinmek gerekmektedir. Moral; bir insana veya insan grubuna hakim olan iklim veya atmosfer olarak tanımlanabilir. Moral dinamik bir kavramdır ve onu yükseltmek için devamlı özen gereklidir. İşyerinde moral, orada hüküm süren çeşitli unsurların ortaklaşa ortaya koydukları bir üründür. Bu unsurlar şu şekilde sıralanabilir (7): örgüt yapısı, gözetim şekli, çalışma koşulları, iş tatmini, personelin iş dışındaki yaşamı. Personelin iş tatmini ve motivasyonuyla ilgili ortaya çıkabilecek diğer memnuniyetsizlikler şu şekilde sıralanabilir: İşin yapılış koşullarına ve iş aletlerine bağlı şikayet ve tatminsizlikler, belli bir işte çalışma sonu- cunda elde edilecek maddi çıkarlara ilişkin şikayet ve tatminsizlikler, takdir edilme ve sosyal prestij durumlarına ilişkin şikayet ve tatminsizlikler.

\section{SONUÇ}

Kurumların başarılı olması çalışanlarına ve çalışanlarının ortaya koyduğu performansa bağlı olmakla birlikte çalışanların performansı yüksek düzeyde tatmin edilmiş olmalarıyla yakından ilişkilidir. Diğer taraftan yapılan araştırmalar örgütsel bağlılığı yüksek olan çalışanların görevlerini yerine getirmede ve kurumsal hedeflere ulaşmada ekstra çaba gösterdiklerini ortaya koymaktadır. Çağımızda yaşanan yoğun rekabet ve değiş̧imin getirdiği stres, çatışma, moral bozukluğu ve çalışanlar arasında iletişimsizliğin çalışanları demoralize ettiği düşünülürse kurumların, çalışanların işine ve kurumuna yönelik tutumlarını belirli aralıklarla ölçmesinin önem taşıdığı ortaya çıkmaktadır (8).

Toplam kalite yönetimi, mükemmellik yaklaşımı, personel güçlendirme gibi yeni yönetim model ve araçları, örgüt içindeki bireylerin önemsenmesini gerekli kılmaktadır. Personelin fikirlerinin önemsenmesi ve kendisine işle ilgili veya iş dışı her konuda destek olunması onların performanslarını artıracaktır (9). Ücret yetersizliklerinin giderilmesi ve personelin fikirlerinin önemsenmesi örgütsel destek algılamasını ve kurumsal bağlılığı arttıran faktörler olarak saptanmıştır. Kurumsal hedefler ve planlar belirlenirken çalışanların fikirlerinin de alınmasının kurum felsefesinin benimsenmesi ve kurumsal bağlılığın sağlanmasında önemli olduğunu düşünmekteyiz. Etkin insan kaynakları uygulamaları için kendimize bazı temel sorular sorarak başlayabiliriz.

Insan Kaynakları Stratejisi; Kurumsal bir insan kaynakları stratejimiz var mı? Yazılı mı? İnsan kaynakları stratejimiz kurumsal amaç ve hedeflerimizle örtüşüyor mu? İnsan Kaynakları Bilgi Sistemi; Çalışanlarla ilgili ihtiyaç duyduğumuz tüm bilgilere her yerden anında ulaşabiliyor muyuz? Özlük, Bordro ve Mevzuat ile ilgili tüm işlemlerimiz tek araçla kolayca yapabiliyor muyuz? İnsan Kaynakları Planlama; İşimiz içim gerekli olan ideal kadro sayısını biliyor muyuz? Hangi çalışanlarımız pozisyon için gerekli yetkinliklere sahip, hangileri sahip değil? Seçme ve 
Yerleştirme; Doğru pozisyona doğru kişiyi alabiliyor muyuz? Kuruluşta bulunan her pozisyon için yetkinlik ve yeterlilikler belirlenmiş mi? Oryantasyon; İşe yeni başlayan çalışandan kısa sürede verim elde edebiliyor muyuz? Oryantasyon süreci planlanan ve takip edilen bir yazılıma sahip miyiz? Oryantasyon süreci başarısını ölçebiliyor muyuz? Eğitim Yönetimi; Etkin eğitim yönetimi gerçekleştirebiliyor muyuz? Eğitim planlamalarımızı kategori, eğitim adı, içerik, yer, eğitmen ve doğru çalışan seçimi bazında yapabiliyor muyuz? Kariyer Planlama ve Yedekleme; Yüksek potansiyelli, liderlik becerisi olan çalışanları belirleyebiliyor ve geliştirebiliyor muyuz? Yönetici ve çalışanlarımız için uzun vadeli bir kariyer planımız var mı? Kritik pozisyonlar belirlenmiş mi? Bu pozisyonlar için yedekleme yapılmış mı? Performans Yönetimi; Çalışanlarımızın verimliliğini ve başarısını doğru ölçebiliyor muyuz? Ve hedeflerimiz ile uyumlu bir performans sistemimiz var mı? Performans sonuçlarını karar süreçleri ve çalışan gelişiminde etkili kullanabiliyor muyuz? Ücret Yönetimi; Adil ve

\section{KAYNAKLAR}

1. Bakan i. Çağdaş Yönetim Yaklaşımları. İstanbul: Beta; 2013. p. 39.

2. Akıncı Z. Turizm Sektöründe işgören iş Tatminini Etkileyen Faktörler: Beş Yıldızlı Konaklama Iş̧letmelerinde Bir Uygulama. Akdeniz iiBF Dergisi 2002; 1-25.

3. Aslantekin F. Sağlık Hizmetlerinde Kalite Deneyimi: Dr. Ekrem Hayri Üstündağ Kadın Hastalıkları ve Doğum Hastanesi Örneği. Fırat Sağlık Hizmetleri Dergisi 2007; 2: 57.

4. Aslan Ş. Sağlık İşletmelerinde Ekip Yönetimi: Fırsatlar ve Sınırlılıklar. Standart Ekonomik ve Teknik Dergisi 2004; 43: $17-23$

5. Özer A, Çakıl E. Sağlık Hizmetlerinde Hasta Memnuniyetini Etkileyen Faktörler. Tıp Araştırmaları Dergisi 2007; 5: 140-3. dengeli bir ücret sistemine sahip miyiz? Ücretler ile ilgili verileri sağlıklı raporlayarak analiz edebiliyor muyuz? Ödüllendirme; Görevlerinde üstün gayret gösteren verimliliği artıran, yenilikler bulan, kuruluşu muhtemel bir zarardan koruyan çalışanları tespit ederek, taltif ediyor muyuz? Motivasyon; Etkinlik ve organizasyonlarımızın planlanması, duyurulması ve gerçekleştirilmesi çalışmalarını sahip olduğumuz yazılım aracılı̆̆ıyla kolayca yapabiliyor muyuz? (10)

İşyerinde personelin memnuniyetini sağlamak ve bağlılığını arttırmak için yöneticiler tarafından bu sorular öncelikle cevaplanmalı ve cevaplara göre stratejik kararlar alınıp uygulanmalıdır. Bu yolla da personel memnun edilmiş ve kurumsal bağlılığı güçlenmiş olacaktır.

\section{Teşekkür}

Çalışmamıza yayın aşamasında verdikleri desteklerden dolayı Doç. Dr. Alper Ötünçtemur ve Stj. Av. Eylül Can Köse'ye teşekkür ederiz.
6. Ünalan D. Bir Üniversite Hastanesinde Çalışan Sekreterlerde iş̧ Memnuniyeti. Hacettepe Sağlık Idaresi Dergisi 2006; 9: 1-18.

7. Eren E. Örgütsel Davranış ve Yönetim Psikolojisi. İstanbul: Beta; 2008. p. 197-240.

8. Sevinç $i$, Şahin A. Kamu Çalışanlarının Örgütsel Bağlıı ı̆ı: Karşılaştırmalı Bir Çalışma. Maliye Dergisi 2012; 62: 266-81.

9. Vural F. Sağlık Çalışanlarında Memnuniyet, Kurumda Kalma ve Örgütsel Bağlıı̆̆a Etki Eden Faktörler. Balıkesir Sağlık Bilimleri Dergisi 2012; 1: 137-44.

10. http://www.workcube.com/etkin-insan-kaynaklari-yonetimi (Erişim Tarihi:24.3.2015). 